\title{
PENGARUH PUASA TERHADAP PERTUMBUHAN DAN POLA KEMATIAN PADA BENIH IKAN KERAPU TIKUS, Cromileptes altivelis
}

\author{
Ketut Maha Setiawati, John Haryanto Hutapea, dan Widianingsih
}

\begin{abstract}
ABSTRAK
Penelitian ini dilakukan untuk mengetahui pengaruh lamanya puasa terhadap pertumbuhan dan sintasan benih kerapu tikus dan pola kematian benih yang diakibatkan oleh pemuasaan (tanpa diberi pakan) secara terus-menerus. Penelitian dilakukan dengan 2 tahap percobaan yaitu: percobaan pertama, pengaruh perbedaan lamanya puasa terhadap pertumbuhan yuwana kerapu tikus, dan percobaan kedua dilakukan untuk mengetahui pola kematian dari yuwana kerapu tikus dengan berbagai ukuran setelah dipuasakan secara terus-menerus sampai mati. Penelitian dilakukan di Balai Besar Riset Perikanan Budidaya Laut Gondol. Percobaan 1 dilakukan dengan menggunakan hewan uji dengan bobot 2-5 g dan panjang total 5,05-8,00 cm, dengan perlakuan: (A) tanpa puasa (kontrol), (B) puasa selama 2 hari, (C) puasa selama 4 hari, (D) puasa selama 6 hari, dan (E) puasa selama 8 hari. Sedangkan percobaan 2 dilakukan pada hewan uji yang berbeda ukurannya yaitu: (A) 7,0-12 g; (B) 3,0-6,0 g; dan (C) 0,5-0,8 g. Setelah itu ikan-ikan tersebut dipuasakan secara terus-menerus, sampai ikan mati. Hasil penelitian percobaan 1 menunjukkan bahwa lamanya puasa 2, 4, dan 6 hari (B, C, dan D) tidak berbeda nyata dengan kontrol (tanpa puasa) terhadap pertumbuhan dan sintasan yuwana kerapu tikus. Sedangkan perlakuan kontrol $A, B, C$, dan $D$ berbeda nyata dengan perlakuan $E$, di mana pertumbuhan pada perlakuan $E$ lebih rendah daripada perlakuan lainnya. Hasil percobaan 2 menunjukkan bahwa kelompok ikan kecil C $(0,5-0,8 \mathrm{~g})$ lebih cepat mati daripada kelompok $A$ dan $B$.
\end{abstract}

\section{ABSTRACT: Effect of starvation on growth and mortality patterns on juveniles humpback grouper, Cromileptes altivelis. By: Ketut Maha Setiawati, John Haryanto Hutapea, and Widianingsih}

The experiment aimed to study the effect of starvation on the growth, survival rate, and pattems of mortality if the juveniles without feeding for a long time. The study was conducted in 2 experiments: 1. effect of the length of starvation on growth of juveniles humpback grouper; and 2. mortality patterns on different sizes of juveniles which were starved for certain days. The experiment was conducted at Gondol Research Institute for Mariculture. Juvenile sizes of 2-5 $g$ were treated with: A. no starvation, B. 2-day starvation, C. 4-day starvation, D. 6-day starvation, and E. 8day starvation. The first experiment were conducted for 30 days. The second experiment was conducted to know how long the juvenile can survive without feeding. Result of the first experiment showed that the effects of starvation for $2,4,6$ days $(B, C, D)$ were not significantly different compared to control (no starvation) on growth and survival of juveniles. On the other hand, Control $A$, $B, C, D$ were significantly different with $E$. The growth at $E$ treatment was worse than others. The result of the second experiment showed that the group of small fishes (C: 0.5-0.8 g) died faster compared there of to $A$ and $B$.

\section{KEYWORDS: $\quad$ starvation, juvenile, growth, survival}

\section{PENDAHULUAN}

Budi daya ikan kerapu E. salmoides (Teng \& Chua, 1980) sudah dimulai sejak tahun 1973 di Malaysia, sedangkan untuk jenis $E$. akaara sudah dibudidayakan di Hongkong sejak tahun 1978 (Tseng \& Ho, 1988). Di Indonesia telah diidentifikasi terdapat 20 ge-nus dan 40 spesies ikan kerapu (Purba \& Ahmad, 1989) dan baru sebagian kecil spesies yang dibudidayakan.

Usaha budi daya ikan kerapu saat ini mulai berkembang dengan tersedianya benih dan didukung oleh harga serta permintaan pasar yang semakin meningkat, terutama untuk ekspor ke Hongkong,
China, Singapura, dan Jepang. Ikan kerapu mempunyai harga cukup mahal. Hal itu memacu intensitas penangkapan semakin meningkat dan dikhawatirkan populasinya di alam terancam punah. Oleh karena itu, upaya pembenihan dengan produksi massal benih ikan kerapu perlu diintensifkan. Di samping pemenuhan benih untuk budi daya juga untuk restocking dalam rangka pemulihan populasinya di alam.

Beberapa jenis ikan kerapu telah berhasil dipijahkan di dalam bak-bak secara terkontrol, antara lain:

\footnotetext{
*) Peneliti pada Balai Besar Riset Perikanan Budidaya Laut, Gondol
} 
ikan kerapu macan E. fuscoguttatus (Muchari et al., 1991; Mayunar et al., 1991); ikan kerapu bebek Cromileptes altivelis (Tridjoko et al., 1996); kerapu sunu Plectropoma aerolatus (Slamet \& Rukmana, 1996).

Seiring dengan meningkatnya budi daya kerapu di tambak maupun di keramba jaring apung, maka permintaan benih di berbagai daerah baik di dalam maupun di luar negeri (Taiwan, Singapore, dan Malaysia) semakin meningkat. Keberhasilan teknologi perbenihan di Balai Besar Riset Perikanan Budidaya Laut Gondol mendorong petani nelayan di sekitarnya dalam memproduksi benih kerapu tikus dan macan. Benih-benih tersebut pada akhirnya akan dipasarkan ke berbagai lokasi budi daya.

Terjadinya beberapa kasus kematian selama pengangkutan benih, antara lain diakibatkan benih tersebut sebelum diangkut tidak dipuasakan terlebih dahulu, sehingga ikan tersebut banyak yang muntah, bahkan dapat mengakibatkan kematian selama transportasi. Oleh sebab itu penelitian ini dilakukan untuk mengetahui pengaruh lamanya puasa terhadap pertumbuhan benih dan pola kematian benih yang diakibatkan oleh pemuasaan secara terus-menerus.

\section{BAHAN DAN METODE}

\section{Percobaan 1}

Penelitian dilakukan di Balai Besar Riset Perikanan Budidaya Laut, Gondol, menggunakan bak fiber dengan volume $200 \mathrm{~L}$ sebanyak 5 buah. Hewan uji yang digunakan yaitu yuwana ikan kerapu tikus (Cromileptes altivelis) dengan bobot tubuh antara 2-5 $\mathrm{g}$; dengan rata-rata bobot tubuh $3,6 \mathrm{~g}$; dan kisaran panjang total $5,05-8,00 \mathrm{~cm}$. Ikan uji tersebut dikelompokkan menjadi 5 kelompok yang ditempatkan pada masing-masing bak. Setiap bak mendapat perlakuan yang berbeda yaitu: A. tanpa puasa (kontrol), B. puasa selama 2 hari, C. puasa selama 4 hari, D. puasa selama 6 hari, dan E. puasa selama 8 hari. Kepadatan ikan setiap bak 25 ekor/bak, pergantian air dilakukan setiap hari dengan sistem air mengalir. Pakan diberikan sampai kenyang. Penyiponan sisa pakan dilakukan setiap hari. Penelitian dilakukan selama 30 hari.

Parameter yang diukur adalah bobot tubuh, panjang total, dan suhu air. Pengamatan pertumbuhan dilakukan setiap 5 hari sekali dengan cara mengambil ikan sebanyak 25 ekor/bak. Kemudian ikan tersebut diukur dan ditimbang satu per satu dengan menggunakan timbangan Libror. Di atas timbangan tersebut sudah ditempatkan mangkuk yang berisi air agar ikan yang ditimbang tidak stress.

\section{Percobaan 2}

Percobaan ke-2 dilakukan di Balai Besar Riset Perikanan Budidaya Laut, Gondol, dengan menggunakan bak fiber $100 \mathrm{~L}$ sebanyak 3 buah yang diisi hewan uji sebanyak 25 ekor/bak. Ukuran hewan uji yang digunakan sebagai perlakuan yaitu: $A$. bobot antara 7,0--12 g panjang total 7,9--9,5 cm; B. bobot antara $3,0--6,0 \mathrm{~g}$ panjang total $5,5--7,0 \mathrm{~cm}$; dan $\mathrm{C}$. bobot antara 0,5--0,8 g panjang total 2,5--3,8 cm. Masing-masing kelompok ikan ditempatkan pada bak yang berbeda. Setelah itu ikan-ikan dipuasakan secara terus-menerus sampai ikan tersebut mati. Pergantian air dilakukan setiap hari dengan sistem air mengalir. Penyiponan dilakukan setiap hari pada 7 hari pertama kemudian disipon setiap seminggu sekali. Penelitian dilakukan sampai semua ikan uji mati.

Parameter yang diamati yaitu panjang dan bobot tubuh dilakukan setiap 5 hari sekali dengan cara mengambil sampel sebanyak 8 ekor/bak. Setiap hari juga dilihat apakah ada ikan uji yang mati. Jika ada ikan uji yang mati maka harus segera diukur panjang dan bobot tubuh ikan yang mati tersebut.

Metode yang digunakan untuk menduga siritasan (S) dan pertumbuhan nisbi sesuai dengan formula Effendie (1992) yaitu dengan membandingkan ikan yang hidup pada akhir suatu periode dengan jumlah ikan yang hidup pada awal periode: $\mathrm{S}=\mathrm{Nt} / \mathrm{No}$. Pertumbuhan nisbi yaitu panjang atau bobot yang dicapai dalam suatu periode waktu tertentu dibandingkan dengan panjang atau bobot pada awal periode tersebut: $h=\left(I_{3}-I_{2}\right) / I_{2}$ di mana $I_{2}$ adalah bobot atau panjang awal dan $\mathrm{I}_{3}$ adalah bobot atau panjang akhir. Sedangkan pertumbuhan harian dihitung berdasarkan persamaan $\left(I_{3}-I_{2}\right) /\left(t_{3}-t_{2}\right)$; di mana $I_{3}$ bobot akhir, $I_{2}$ bobot awal, $\mathrm{t}_{3}$ waktu akhir (hari) dan $\mathrm{t}_{2}$ waktu awal.

\section{HASIL DAN BAHASAN}

\section{Percobaan 1}

Tabel 1 menunjukkan bahwa pertumbuhan benih kerapu tikus dengan ukuran bobot tubuh awal 3,473,89 g setelah dipuasakan selama 2-6 hari (perlakuan B, C, dan D) pertumbuhan relatif dan bobot akhir tidak berbeda nyata $(P>0,05)$ dengan kontrol (tanpa puasa). Sedangkan pertumbuhan relatif dan bobot akhir pada perlakuan $E$ (puasa selama 8 hari) berbeda nyata dengan perlakuan $A, B, C$, dan $D(P<0,05)$. Begitu juga pada Gambar 1 terlihat bahwa pada perlakuan A, B, C, dan D mempunyai pertambahan bobot yang hampir sama, sedangkan perlakuan $\mathrm{E}$ mempunyai pertambahan bobot yang lebih rendah.

Pada Gambar 2 terlihat bahwa pertumbuhan bobot harian ikan dari perlakuan kontrol dan pemuasaan 
Tabel 1. Bobot awal, bobot akhir, dan pertumbuhan relatif pada yuwana kerapu tikus selama 30 hari pemeliharaan

Table 1. Initial, final weight, and relative growth of juvenile humpback grouper during 30 days rearing

\begin{tabular}{|c|c|c|c|c|}
\hline $\begin{array}{l}\text { Perlakuan } \\
\text { (Treatment) }\end{array}$ & $\begin{array}{c}\text { Bobot awal (g) } \\
\text { Initial weight } \\
\text { (g) }\end{array}$ & $\begin{array}{l}\text { Bobot akhir }(g) \\
\text { Final weight }(g)\end{array}$ & $\begin{array}{c}\text { Pertumbuhan } \\
\text { relatif } \\
\text { Relative } \\
\text { growth }\end{array}$ & $\begin{array}{c}\text { Sintasan (\%) } \\
\text { Survival } \\
\text { rate (\%) }\end{array}$ \\
\hline $\begin{array}{l}\text { A (Kontrol, tanpa puasa) } \\
\text { A (Control, without starvation) }\end{array}$ & $3.63^{a)}$ & $8.57^{a)}$ & $1.360^{a)}$ & 100 \\
\hline $\begin{array}{l}B(2 \text { hari puasa) } \\
B(2 \text { days for stanation) }\end{array}$ & $3.89^{a)}$ & $8.98^{a)}$ & $1.308^{a)}$ & 100 \\
\hline $\begin{array}{l}\text { C ( } 4 \text { hari puasa) } \\
\text { C (4 days for starvation) }\end{array}$ & $3.63^{a)}$ & $8.17^{a)}$ & $1.251^{\text {a) }}$ & 100 \\
\hline $\begin{array}{l}\text { D (6 hari puasa) } \\
D \text { (6 days for starvation) }\end{array}$ & $3.47^{a)}$ & $7.85^{\mathrm{a})}$ & $1.271^{\text {a) }}$ & 100 \\
\hline $\begin{array}{l}\text { E ( } 8 \text { hari puasa) } \\
E \text { ( } 8 \text { days for starvation) }\end{array}$ & $3.57^{a)}$ & $6.15^{b)}$ & $0.723^{b)}$ & 100 \\
\hline
\end{tabular}

Catatan/note: Nilai dalam kolom yang diikuti dengan huruf yang sama tidak berbeda nyata $(P>0,05)$

Values in column followed by the same superscript are not significantly different $(P>0.05)$

selama $2,4,6$, dan 8 hari mempunyai kurva yang naik turun selama 30 hari pemeliharaan. Pada perlakuan pemuasaan 6 dan 8 hari sempat terjadi penurunan bobot, yang menunjukkan nilai minus (Gambar 2), tetapi pertumbuhan meningkat pada hari ke-10 (setelah diberi pakan). Tetapi pada hari ke-30 pertumbuhan harian pada perlakuan $A$ dan perlakuan D serta $E$ terlihat pada titik yang sama, sehingga perlu dilakukan penelitian lanjutan dengan lama pemeliharaan lebih dari 30 hari.

\section{Percobaan 2}

Hubungan panjang dan bobot ikan yang tumbuh normal (diberi pakan setiap hari sampai kenyang) dan ikan yang mati karena puasa disajikan pada Gambar 3. Adapun ikan yang tumbuh normal mempunyai kurva hubungan panjang dan bobot yang lebih tinggi daripada ikan yang mati karena dipuasakan. Ikan-ikan mati karena dipuasakan secara visual tampak lebih kurus daripada ikan-ikan yang tumbuh normal. Adapun for-

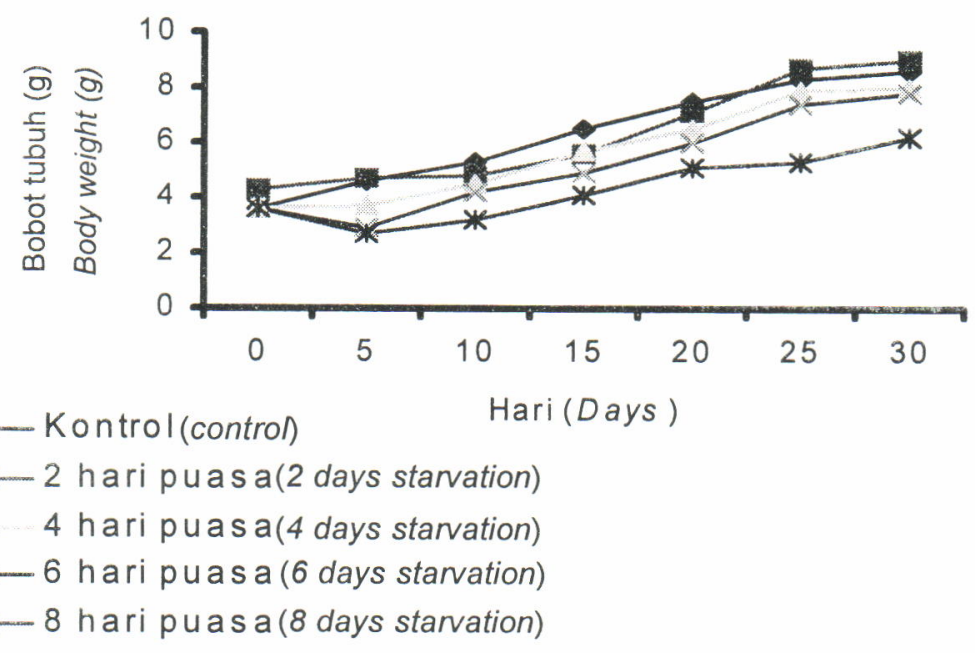

Gambar 1. Hubungan antara perbedaan lamanya puasa terhadap pertambahan bobot tubuh benih kerapu tikus selama 30 hari

Figure 1. The effect of different starvation on body weigth gain of humpback grouper during 30 days rearing 


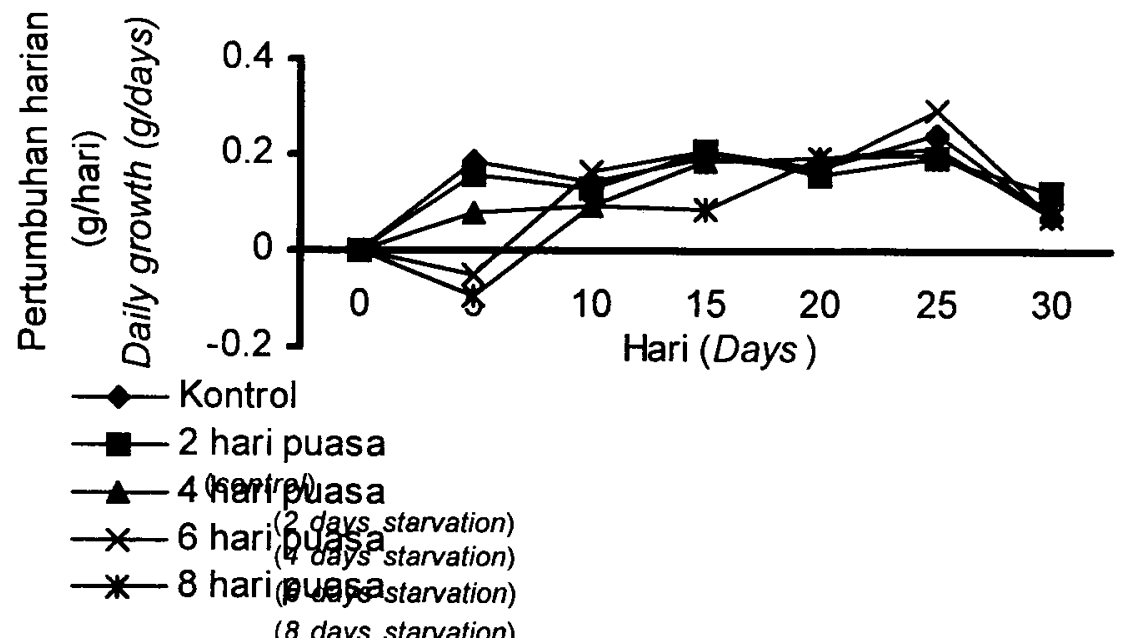

Gambar 2 Pertambahan bobot harian pada benih kerapu tikus setelah dipuasakan

Figure 2. Daily growth rate of juvenile humpback grouper during stanation

mula pertumbuhan ikan yang tumbuh normal yaitu: $W=0,0164 L^{2.9691}$. Formula pertumbuhan ikan yang mati karena puasa; $W=0,0090 L^{2,8974}$, di mana $W=$ bobot tubuh $(\mathrm{g})$ dan $\mathrm{L}$ panjang total $(\mathrm{cm})$. Nilai b pada ikan yang tumbuh normal yaitu 2,969 dan nilai b pada ikan yang mati karena dipuasakan yaitu 2,897 . Jika dibandingkan, nilai b pada yuwana ikan flounderyang hidup yaitu 2,683 dan nilai b pada ikan yang mati karena dipuasakan yaitu 2,380 (Tanda, 1989). mulai terjadi setelah 10 hari dipuasakan dan pada hari ke-50 semua ikan ukuran kecil sudah mati. Pengaruh pemuasaan terhadap sintasan pada benih ukuran bobot ikan 0,5-0,8 g telah terlihat 10 hari setelah dipuasakan dan pemanfaatan energi yang terkandung dalam tubuh ikan maksimum hanya hingga 50 hari. Sementara pada ikan ukuran 3-6 g dan 6-12 g pengaruh pemuasaan terhadap sintasan terjadi setelah 50 hari dipuasakan dan pemanfaatan energi yang

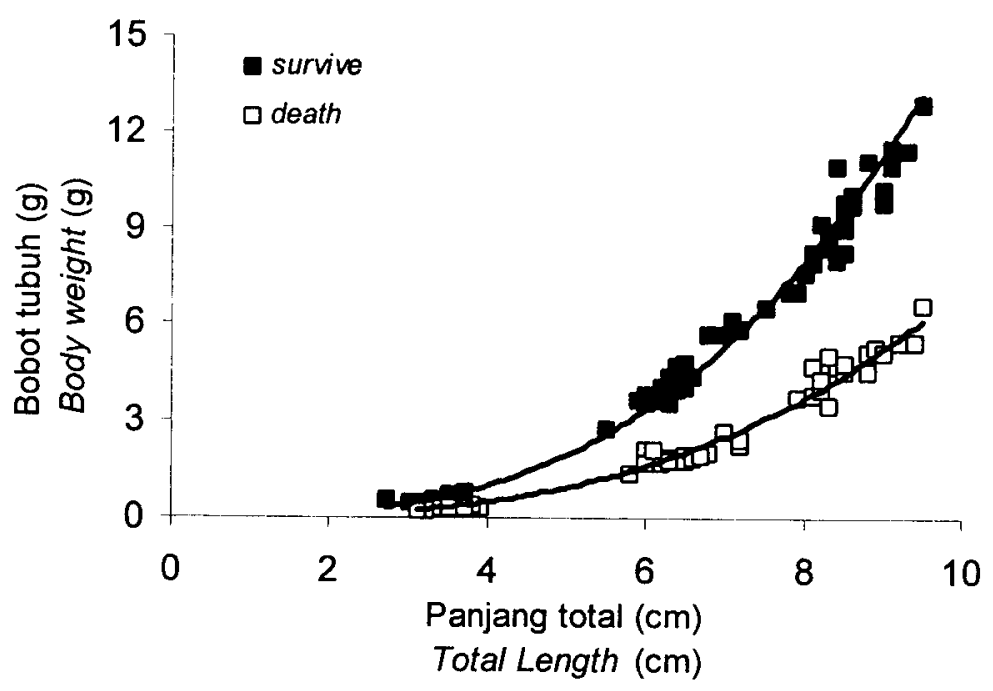

Gambar 3. Kurva hubungan panjang bobot pada benih kerapu bebek (Cromileptes altivelis) pada kondisi pertumbuhan normal dan pada perlakuan setelah dipuasakan selama 55 hari

Figure 3. Weight-length relation of humpback grouper in normal and 55 days starvation condition for old

Kelompok ukuran ikan yang lebih kecil $(0,5-0,8 \mathrm{~g})$ lebih cepat mati jika dipuasakan daripada ikan yang lebih besar (3-6 g) dan (7-12 g) (Gambar 4). Pada ikan yang lebih kecil $(0,5-0,8 \mathrm{~g})$ penurunan sintasan terkandung dalam tubuh ikan tersebut maksimum mampu sampai 90 hari pemuasaan. Pada hari ke-90 kedua kelompok ikan tersebut mati $100 \%$. Sehingga dapat dikatakan bahwa kelompok ikan ukuran $3-6 \mathrm{~g}$ 


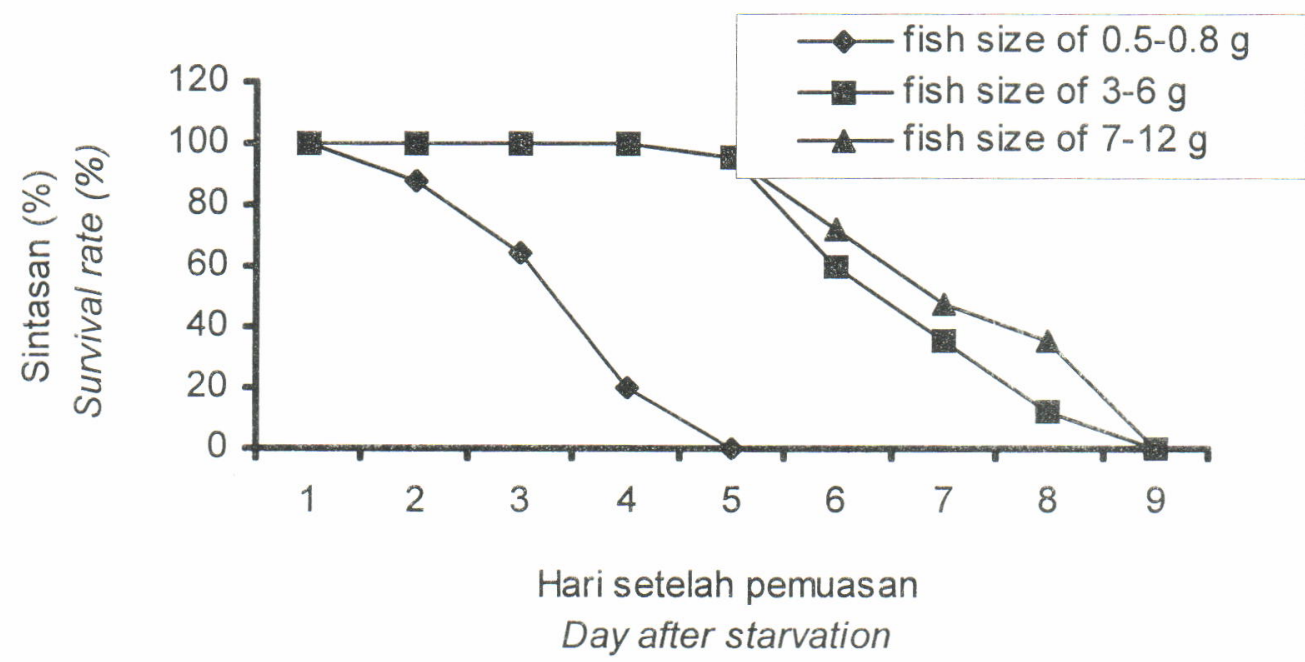

Gambar 4. Kurva hubungan tiga kelompok ukuran ikan terhadap sintasan benih selama dilakukan pemuasaan Figure 4. Survival rate curve of different size juvenile grouper during starvation

dan $7-12 \mathrm{~g}$ mempunyai pola kematian yang hampir sama. Begitu juga pada yuwana ikan flounder semakin kecil ukuran ikan semakin cepat ikan tersebut mati. Yuwana ikan flounder yang berukuran $5,85 \mathrm{~cm}$ mulai mati setelah 20 hari dipuasakan dan yuwana yang berukuran $10 \mathrm{~cm}$ mulai mati setelah 50 hari dipuasakan dan mati 100\% pada hari ke-90 (Tanda, 1989).

Kualitas air selama penelitian yaitu suhu berkisar $28,9^{\circ} \mathrm{C}-30^{\circ} \mathrm{C}$; $\mathrm{pH}$ air 8,72-8,83; dan kecepatan pergantian air selama sehari yaitu $300 \%$.

\section{KESIMPULAN DAN SARAN}

Benih ikan kerapu tikus dengan bobot tubuh 2-5 g dapat dipuasakan sampai 6 hari tanpa mempengaruhi pertumbuhan dan sintasan selanjutnya.

Benih ikan dengan ukuran 3-12 g lebih lama dapat memanfaatkan energi dalam tubuhnya (maximum 90 hari) daripada ukuran ikan 0,5-0,8 g (maximum 50 hari).

Untuk percobaan 1, disarankan untuk melanjutkan penelitian pemuasaan dengan lama pemeliharaan yang lebih lama (lebih dari 1 bulan) untuk mengetahui pengaruh dari pemuasaan selama 8 hari. Untuk pengangkutan benih kerapu tikus pada jarak jauh, benih tersebut dapat dipuasakan sampai 6 hari asal kualitas airnya tetap bagus.

\section{UCAPAN TERIMA KASIH}

Ucapan terima kasih diberikan kepada Komang Suarsana yang telah membantu pelaksanaan penelitian ini, dan seluruh teknisi di MSH (Muslim Romdlianto, Buda, Feri, Dedi Rohaniawan, dan Karyanto) yang telah mempersiapkan benih kerapu tikus.

\section{DAFTAR PUSTAKA}

Effendie, M.I. 1992. Metoda Biologi Perikanan. Yayasan Agromedia. Jakarta, $112 \mathrm{pp}$.

Mayunar, P.T. Imanto, S. Diani dan T. Yokokawa 1991. Pemijahan ikan kerapu macan, Epinephelus fuscoguttatus. Buii. Pen. Perikanan (Terbitan khusus) 2: 15--22.

Tanda, M. 1989. Correlation between starvation resistance and body length in the juveniles of hatchery reared flounder Paralichthys olivaceus. Suisanzozhoku 37: 235-239.

Muchari, A. Supriatna, R. Purba, T. Ahmad, dan H. Kohno. 1991. Pemeliharaan larva kerapu macan, Epinephelus fuscoguttatus. Buil. Pen. Perikanan (Terbitan khusus) 2: 43--52.

Purba, R. dan T. Ahmad. 1989. Studi pendahuluan tanggapan ikan kerapu lumpur (Epinephelus suillus) terhadap pakan buatan. J. Penel. Budidaya Pantai. 15(2): 72--75.

Slamet, B. dan T. Rukmana. 1996. Pengamatan pada pemijahan induk dan perkembangan awal larva ikan kerapu sunu, Plectropoma aerolatus. Prosiding Seminar Nasional Biologi XI. 11 pp.

Teng, S.K. and S.K. Chua. 1980. Effect of stocking density on the growth of estuary grouper Epinephelus salmoides Maxwell, cultured in floating net cages. Aquaculture. 15: 273--287

Tseng, W.Y. and S.K. Ho. 1988. Grouper Culture. A Practical Manual, the Biology and Culture of Red Grouper Epinephelus akaara (Temminck \& Schlegel). Chien Cheng Publisher. $134 \mathrm{pp}$.

Tridjoko, B. Slamet, D. Makatutu, dan K. Sugama. 1996. Pengamatan dan perkembangan telur ikan kerapu bebek (Cromileptes altivelis) pada bak secara terkontrol. J. Penelitian Perikanan Indonesia II (2): 55--62. 